\title{
Primary Necrobiotic Xanthogranulomatous Sialadenitis with Submandibular Gland Localization without Skin Involvement
}

\author{
Myunghee Kang · Na Rae Kim \\ Dong Hae Chung · Jae Yeon Seok \\ Dong Young $\mathrm{Kim}^{1}$ \\ Departments of Pathology and \\ ${ }^{1}$ Otorhinolaryngology-Head and Neck Surgery, \\ Gil Medical Center, Gachon University \\ College of Medicine, Incheon, Korea \\ Received: November 26, 2018 \\ Revised: December 28, 2018 \\ Accepted: January 8, 2019 \\ Corresponding Author \\ Na Rae Kim, MD \\ Department of Pathology, Gil Medical Center, \\ Gachon University College of Medicine, \\ 21 Namdong-daero 774beon-gil, Namdong-gu, \\ Incheon 21565, Korea \\ Tel: +82-32-460-3073 \\ Fax: +82-32-460-2394 \\ E-mail: clara_nrk@gilhospital.com
}

\begin{abstract}
Necrobiotic xanthogranulomatous reaction is a multiorgan, non-Langerhans cell histiocytosis with an unknown etiology. Occurrence in the salivary gland is extremely rare. We recently identified a case of necrobiotic xanthogranulomatous sialadenitis in a 73-year-old Korean woman who presented with a painless palpable lesion in the chin. There was no accompanying cutaneous lesion. Partial resection and subsequent wide excision with neck dissection were performed. Pathological examination showed a severe inflammatory lesion that included foamy macrophages centrally admixed with neutrophils, eosinophils, lymphocytes, plasma cells, and scattered giant cells, as well as necrobiosis. During the 12-month postoperative period, no grossly remarkable change in size was noted. Necrobiotic xanthogranulomatous inflammation may be preceded by or combined with hematologic malignancy. Although rare, clinicians and radiologists should be aware that an adhesive necrobiotic xanthogranuloma in the salivary gland may present with a mass-like lesion. Further evaluation for hematologic disease and close follow-up are needed when a pathologic diagnosis is made.
\end{abstract}

Key Words: Necrobiotic xanthogranuloma; Salivary glands; Sialadenitis; Hematologic neoplasms
Necrobiotic xanthogranuloma (NXG) is a histiocytic disease, commonly found in the subcutaneous tissue of the periorbital area. ${ }^{1}$ To the best of our knowledge, only one case of NXG and three cases of primary xanthogranulomatous sialadenitis have been reported. ${ }^{2-5} \mathrm{NXG}$ is considered a systemic disease that may involve the skin and extracutaneous sites, including the lung, myocardium, larynx, pharynx, intestines, and even ovaries. ${ }^{6}$ Many NXG patients have shown associated paraproteinemia and monoclonal gammopathy, and there are currently no standardized treatment modalities. ${ }^{1}$ Here, we report a rare case of localized primary necrobiotic xanthogranulomatous sialadenitis that presented as a fibrotic palpable mass without skin lesion. This is the first case involving the submandibular gland and that was preoperatively regarded as a tumoral mass.

\section{CASE REPORT}

\section{Clinical summary}

A 73-year-old woman presented with a painless palpable left chin mass, which had persisted for the previous eight months. There was no accompanying skin lesion. She had no significant medical history, except hypertension, and denied any history of trauma to the left side of the chin. Several conglomerated high density lesions that involved periglandular soft tissue and measured $1.7 \mathrm{~cm}$ were found in the left submandibular gland using head and neck computed tomography (Fig. 1A). Fine needle aspiration was performed (Fig. 1B). During the 3-month follow-up period, the palpable mass increased from 1.7 to $2.8 \mathrm{~cm}$; therefore, the patient underwent surgery. An ill-defined mass located in the submandibular gland and periglandular soft tissue was noted in the operative field. Partial resection was performed because it was impossible to achieve complete resection due to severe adhesion. She was treated with anti-inflammatory medication; however, the mass kept increasing in size and was measured at $4 \mathrm{~cm}$ at 15 months. She underwent a second operation of wide excision of the salivary gland mass and ipsilateral neck node dissection. During the 12-month postoperative period, no grossly remarkable change in size and no abnormalities in blood 

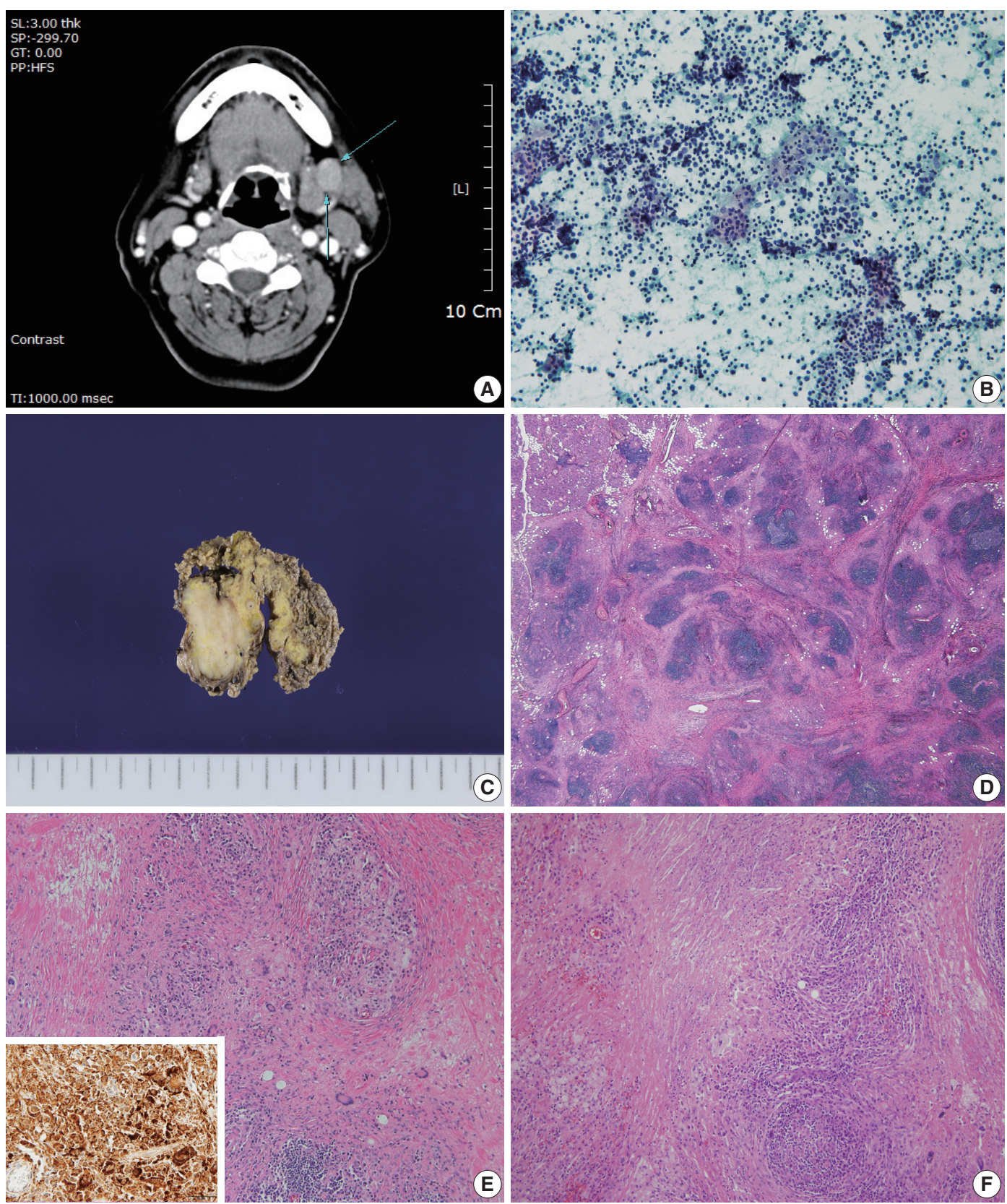

Fig. 1. Necrobiotic xanthogranulomatous sialadenitis. (A) Head and neck computed tomography shows several conglomerated masses in the submandibular gland. (B) Fine needle aspiration cytology reveals many lymphocytes and scattered histiocytes with tingible bodies (PAP). (C) Gross picture of the resected specimen shows a well-circumscribed, ovoid, white-tan mass with yellowish necrotic foci. (D) Necrobiotic xanthogranuloma shows a zone of thick collagen surrounded by lymphohistiocytic palisading granulomas. (E) Foreign body type and Toutontype giant cells are noted (CD68 immunostaining, inset). (F) Cholesterol clefts (upper center) and foam cells are seen adjacent to necrobiosis.

chemistry were noted. She is currently on a follow-up plan and will be seen every 6 months.

\section{Pathological findings}

Fine needle aspiration revealed numerous polymorphous lymphoid cells with scattered epithelioid histiocytes and tingible body macrophages (Fig. 1B). A partially resected specimen was assessed and found to be composed of one reactive follicular hyperplastic lymph node and fragmented soft tissues that showed chronic inflammation with a collection of foamy histiocytes. Occasional granulomas and giant cells were also noted. There was no evidence of malignancy or infection. Later, a fibrotic and very adhesive 
Table 1. Clinicopathologic features of primary xanthogranulomatous sialadenitis

\begin{tabular}{|c|c|c|c|c|c|c|c|c|c|}
\hline \multirow{3}{*}{ Study } & \multirow{3}{*}{$\begin{array}{l}\text { Age } \\
\text { (yr) } \\
\text { /Sex }\end{array}$} & \multirow{3}{*}{$\begin{array}{c}\text { Clinical } \\
\text { presentation }\end{array}$} & \multirow{3}{*}{$\begin{array}{l}\text { Primary } \\
\text { site }\end{array}$} & \multirow{3}{*}{$\begin{array}{l}\text { Cutaneous } \\
\text { involvement }\end{array}$} & \multirow{3}{*}{$\begin{array}{l}\text { Cytology taken from } \\
\text { salivary gland }\end{array}$} & \multicolumn{3}{|c|}{ Histologic findings } & \multirow{3}{*}{ Follow-up } \\
\hline & & & & & & \multicolumn{2}{|r|}{ Salivary gland } & \multirow{2}{*}{$\begin{array}{l}\text { Regional lymph } \\
\text { nodes }\end{array}$} & \\
\hline & & & & & & Necrobiosis & Immunohistochemistry & & \\
\hline $\begin{array}{l}\text { Esson } \\
\text { et al. } \\
(1998)^{2}\end{array}$ & 72/F F & $\begin{array}{l}\text { Painful } \\
\text { palpable } \\
\text { mass at } \\
\text { presentation }\end{array}$ & Parotid & No & $\begin{array}{l}\text { Inadequate } \\
\text { specimen }\end{array}$ & No & $\begin{array}{l}\mathrm{CD}_{68}{ }^{+} \mathrm{CD} 45 \mathrm{RD}^{+} \\
\mathrm{CD} 20^{+}\end{array}$ & $\begin{array}{l}\text { Involvement of } \\
\text { granulomatous } \\
\text { inflammation }\end{array}$ & $\begin{array}{l}\text { Multifocal recurrence of } \\
\text { xanthogranulomatous } \\
\text { inflammation, T-cell } \\
\text { rich, B-cell lymphoma } \\
\text { in small intestine after } \\
9 \text { mo, and died after } \\
22 \mathrm{mo}\end{array}$ \\
\hline $\begin{array}{l}\text { Stephen } \\
\text { et al. } \\
(1999)^{3}\end{array}$ & 56/M P & $\begin{array}{l}\text { Painless } \\
\text { palpable } \\
\text { mass }\end{array}$ & Parotid & No & $\begin{array}{l}\text { Oncocytic epithelioid } \\
\text { cells, lymphoid cells } \\
\text { and degenerate } \\
\text { squamous cells, } \\
\text { mast cells in mucoid } \\
\text { background }\end{array}$ & No & $\mathrm{CD68}^{+}$ & $\begin{array}{l}\text { Reactive } \\
\text { hyperplasia }\end{array}$ & Not described \\
\hline $\begin{array}{l}\text { Zainal } \\
\text { et al. } \\
(2010)^{4}\end{array}$ & $48 / M S$ & $\begin{array}{l}\text { Slow growing } \\
\text { palpable } \\
\text { mass }\end{array}$ & Parotid & No & $\begin{array}{l}\text { Warthin tumor, } \\
\text { which showed no } \\
\text { evidence in surgical } \\
\text { resection }\end{array}$ & Yes & Not described & Not described & $\begin{array}{l}\text { No symptom during } 8 \\
\text { mo }\end{array}$ \\
\hline $\begin{array}{l}\text { Turkmen } \\
\text { et al. } \\
(2012)^{5}\end{array}$ & $52 / \mathrm{M}$ Ir & $\begin{array}{l}\text { Inflamed } \\
\text { mass }\end{array}$ & Parotid & No & $\begin{array}{l}\text { Warthin tumor, } \\
\text { which showed no } \\
\text { evidence in surgical } \\
\text { resection }\end{array}$ & No & $\mathrm{CD}^{\circ} 8^{+}$ & Not described & Not described \\
\hline $\begin{array}{l}\text { Present } \\
\text { case } \\
(2018)\end{array}$ & 73/F P & $\begin{array}{l}\text { Painless } \\
\text { palpable } \\
\text { mass }\end{array}$ & $\begin{array}{l}\text { Subman- } \\
\text { dibular }\end{array}$ & No & $\begin{array}{l}\text { Epithelioid histiocytes } \\
\text { with tingible body } \\
\text { macrophages }\end{array}$ & Yes & $\mathrm{CD} 8^{+} \mathrm{CD} 1 \mathrm{a}^{-}$ & $\begin{array}{l}\text { Reactive } \\
\text { hyperplasia }\end{array}$ & $\begin{array}{l}\text { No symptom } \\
\text { during } 12 \text { mo }\end{array}$ \\
\hline
\end{tabular}

F, female; $M$, male.

salivary gland was widely excised. The cut surface showed a relatively well-demarcated, grayish-white, ovoid-shaped mass that measured $3.5 \times 2.5 \times 1.5 \mathrm{~cm}$ (Fig. 1C). Microscopically, the firm lesion was composed of an admixture of foamy macrophages, plasma cells, and many lymphoid follicles. Extensive band-like collagenous geographic necrosis was noted (Fig. 1D). Both Touton- and foreign body type giant cells were abundant in the periphery of the necrosis (Fig. 1E, F). The growth pattern of the mass was infiltrative with adjacent fibroadipose tissue and skeletal muscles, sparing the lymph nodes. Lymphoplasmacytic infiltration was found in the background of the salivary gland parenchyma. The histiocytic cells were positive for CD68 (KP1, 1:100 dilution, DAKO, Glostrup, Denmark) and negative for CD1a (MTB1, 1:100 dilution, Novocastra, Newcastle upon Tyne, UK) (Fig. 1E, inset). No microorganisms were noted on the acid-fast bacilli, periodic-acid Schiff, or Gomori-methenamine silver stains. No increase in the number of IgG4-positive plasma cells (IgG4, 1:1,000 dilution, Invitrogen, Carlsbad, CA, USA) was found at maximum one positive cell/high power field. The aforementioned histologic findings were compatible with the diagnosis of NXG.

Approval was obtained from our Institutional Review Board (No. GBIRB2018-018) for this case report, with a waiver of in- formed consent.

\section{DISCUSSION}

NXG is a rare histiocytic disease that involves the skin and subcutaneous tissue. Common sites include the periocular area and thorax. ${ }^{1}$ NXG is rare in the head and neck area, and there has been only one case reported in the salivary gland. ${ }^{4} \mathrm{NXG}$ has characteristic histologic features, showing clusters of foamy xanthomatous macrophages, granulomas, and giant cells of foreign body type or Touton-type, cholesterol clefts, and necrobiosis. ${ }^{2}$ The most characteristic findings are extensive necrosis and inflammation with foamy macrophages and giant cells. These features are similar to the findings of previously reported cases of xanthogranulomatous sialadenitis. ${ }^{2,3,7,-9}$ Although there was a lack of detailed information about degree of necrosis, infiltration of foamy cells, and amount of giant cells accumulation, we hypothesize that there is an overlap of xanthogranulomatous sialadenitis and salivary NXG. Reports of xanthogranulomatous sialadenitis are rare, and only six cases have been reported to date. ${ }^{2,3,5,7-9}$ When excluding the secondary changes of preexisting salivary gland lesions, including Warthin tumor, pleomorphic adenoma, and sialolithiasis, only three cases of xanthogranulomatous inflammation were 
identified in the literature. ${ }^{2,3,5}$ No cutaneous lesions were noted in this or previous cases. Three cases were misdiagnosed as Warthin tumor in preoperative cytology, and this misdiagnosis can be attributed to the aspiration cytology that included a mixed population of lymphoid cells and presence of histiocytes of oncocytic and epithelioid features. ${ }^{3}$ These are summarized in Table 1.

NXG is in a category of other histiocytosis syndromes (category D76.3) that has been outlined by the World Health Organization International Classification of Diseases, 10th revision classification system of diseases. Histologic differential diagnoses of NXG include histiocytic lesions, such as necrobiosis lipoidica diabeticorum, juvenile xanthogranuloma, granuloma annulare, foreign-body granuloma, rheumatoid nodules, amyloidosis, xanthoma disseminatum, and Erdheim-Chester disease. ${ }^{1}$ The histiocytes seen in NXG are CD68-positive and CD1a-negative, with no Birbeck granules, which correspond to a non-Langerhans cell histiocytosis. However, a pathologic diagnosis of NXG may be challenging due to its occasionally uncharacteristic features that overlap those of necrobiosis lipoidica diabeticorum. Cholesterol clefts that are more commonly found in NXG can be helpful for ruling out other inflammatory granulomatous lesions. ${ }^{10}$ This should be distinguished from necrobiosis lipoidica diabeticorum and Erdheim-Chester disease by characteristic histology and through clinicoradiologic findings. ${ }^{11}$

The pathogenesis of NXG is still unclear; one hypothesis suggests that the serum monoclonal protein functions as a lipoprotein and induces xanthogranulomatous reaction. Another theory suggests that necrobiosis leads to ischemia. ${ }^{3}$ Some reported cases showed an increased number of IgG4-positive plasma cells. ${ }^{1}$ One study has indicated the presence of spirochetal microorganisms. ${ }^{12}$ There was no evidence of increased $\operatorname{IgG} 4$ deposition in the tissue or serum in this case, and no abnormal findings were noted in blood chemistry. We were not able to detect Borrelia by focusfloating microscopy. Some authors have asserted that fine needle aspiration may induce ischemia. ${ }^{3}$ Fine needle aspiration of the salivary glands is commonly performed; however, there are extremely rare findings of extensive necrosis with xanthogranulomatous inflammation in surgical specimens.

The clinical course of NXG is variable and unpredictable, and recurrence of the lesion and/or multiple dissemination have been reported at other sites. ${ }^{13,14}$ Other cases have shown systemic involvement, including hematologic malignancy and cardiac myopathy. ${ }^{1,4,13}$ About $20 \%$ of patients in a previous study developed hematologic malignancy during the 11-year follow-up period. ${ }^{15}$ Although most of these involved an ocular lesion, one case that involved the salivary gland showed an emergence of lym- phoma after multifocal and multiple recurrence of NXG. ${ }^{2}$ Therefore, although there is no evidence of hematologic malignancy to date, close follow-up is mandatory.

Due to its rarity, there is currently no standardized treatment guideline for NXG, although treatment approaches have included chemotherapy, interferon, plasmapheresis, steroid injections, cryotherapy, radiation, and surgery. In previous cases of necrobiotic xanthogranulomatous sialadenitis, chemotherapy, radiation, and surgical removal have been attempted. ${ }^{13,15}$ More than one of four patients in a previous study experienced NXG recurrence after surgery. ${ }^{14,15}$ Alkylating agents may be proposed, and steroids can be used to maintain remission. ${ }^{14}$ However, it is difficult to achieve complete excision due to adhesion; therefore, additional therapy after surgery is needed in cases without systemic involvement.

Although NXG has distinct pathologic findings, due to its rarity, diagnosing salivary gland NXG remains challenging. Therefore, it is important for clinicians to consider this diagnosis when a patient presents with recurrent adhesive mass with extensive necrotic change. When a diagnosis is made, further evaluation and close follow-up are needed to identify any potentially hidden hematologic malignancies, such as paraproteinemia and lymphoma, even without manifestation of cutaneous or systemic NXG. Here, we reported a rare case of progressing primary necrobiotic xanthogranulomatous sialadenitis with no accompanying skin lesion or hematologic malignancy.

\section{ORCID}

Myunghee Kang: https://orcid.org/0000-0003-4083-888X

Na Rae Kim: https://orcid.org/0000-0003-2793-6856

Dong Hae Chung: https://orcid.org/0000-0002-4538-0989

Jae Yeon Seok: https://orcid.org/0000-0002-9567-6796

Dong Young Kim: https://orcid.org/0000-0001-5485-7198

\section{Author Contributions}

Conceptualization: NRK.

Data curation: DYK.

Formal analysis: JYS

Investigation: MK, DHC.

Project administration: NRK.

Supervision: NRK.

Validation: MK, JYS.

Writing—original draft: MK, NRK.

Writing—review \& editing: MK, NRK, DHC, JYS, DYK. 


\section{Conflicts of Interest}

The authors declare that they have no potential conflicts of interest.

\section{REFERENCES}

1. Wood AJ, Wagner MV, Abbott JJ, Gibson LE. Necrobiotic xanthogranuloma: a review of 17 cases with emphasis on clinical and pathologic correlation. Arch Dermatol 2009; 145: 279-84.

2. Esson MD, Bird E, Irvine GH. Lymphoma presenting as parotid xanthogranulomatous sialadenitis. Br J Oral Maxillofac Surg 1998; 36: 465-7.

3. Stephen MR, Matalka I, Stewart CJ, Mackenzie K. Xanthogranulomatous sialadenitis following diagnosis of Warthin's tumour: a possible complication of fine needle aspiration (FNA). Cytopathology 1999; 10: 276-9.

4. Zainal A, Razif MY, Makhashen M, Swaminathan M, Mazita A. Necrobiotic xanthogranuloma of the parotid gland. J Laryngol Otol 2010; 124: 569-71.

5. Türkmen I, Başsüllü N, Aslan I, Çomunoğlu C, Doğusoy GB. Xanthogranulomatous sialadenitis clinically mimicking a malignancy: case report and review of the literature. Oral Maxillofac Surg 2012; 16: 389-92.

6. Finan MC, Winkelmann RK. Necrobiotic xanthogranuloma with paraproteinemia: a review of 22 cases. Medicine (Baltimore) 1986;
65: $376-88$

7. Cocco AE, MacLennan GT, Lavertu P, Wasman JK. Xanthogranulomatous sialadenitis: a case report and literature review. Ear Nose Throat J 2005; 84: 369-70, 374.

8. Dale JC, Robinson RA. Malakoplakia of the parotid gland. J Laryngol Otol 1988; 102: 737-40.

9. Padfield CJ, Choyce MQ, Eveson JW. Xanthogranulomatous sialadenitis. Histopathology 1993; 23: 488-91.

10. Rose A, Robinson M, Kamino H, Latkowski JA. Necrobiotic xanthogranuloma. Dermatol Online J 2012; 18 : 30.

11. Sung YE, Lee YS, Lee J, Lee KY. Erdheim-Chester disease involving lymph nodes and liver clinically mimicking lymphoma: a case report. J Pathol Transl Med 2018; 52: 183-90.

12. Saeki $H$, Tomita M, Kai H, et al. Necrobiotic xanthogranuloma with paraproteinemia successfully treated with melphalan, prednisolone and skin graft. J Dermatol 2007; 34: 795-7.

13. Miguel D, Lukacs J, Illing T, Elsner P. Treatment of necrobiotic xanthogranuloma: a systematic review. J Eur Acad Dermatol Venereol 2017; 31: 221-35.

14. Zelger B, Eisendle K, Mensing C, Zelger B. Detection of spirochetal micro-organisms by focus-floating microscopy in necrobiotic xanthogranuloma. J Am Acad Dermatol 2007; 57: 1026-30.

15. Ugurlu S, Bartley GB, Gibson LE. Necrobiotic xanthogranuloma: long-term outcome of ocular and systemic involvement. Am J Ophthalmol 2000; 129: 651-7. 